Fournal of Medical Genetics (1970). 7, 413.

\title{
Cytogenetic Studies in a Patient with a De Novo $\mathrm{t}(\mathrm{Cq}-; \mathrm{Gp}+)^{*}$
}

\author{
BARBARA F. CRANDALL, ROBERT E. CARREL, GEORGE L. ADAMS, \\ and ROBERT S. SPARKES†
}

From the Departments of Pediatrics, Psychiatry and Medicine, UCLA School of Medicine, Los Angeles, California 90024, U.S.A.

All the published instances of human translocations involving group $C$ and $G$ chromosomes have been ascertained through a phenotypically abnormal child with an apparent partial C chromosome trisomy. The translocation in a balanced state has been demonstrated in at least one member of each family. We are now reporting a $\mathrm{t}(\mathrm{Cq}-; \mathrm{Gp}+)$ in an 18-year-old girl whose initial chromosome analysis was part of the routine evaluation of children with psychiatric disorders. Her normal physical phenotype suggests that her translocation is probably balanced. The normal karyotypes of her parents and brother indicate that the translocation arose de novo, first manifesting in the proposita. This report includes the results of cytogenetic, dermatoglyphic, and gene marker studies of the proposita and her family.

\section{Materials and Methods}

Chromosome analysis was carried out on peripheral blood lymphocytes, on skin fibroblasts, and with autoradiography. Buccal smears and hair root sheath cells were studied for sex chromatin bodies. Twelve red cell antigens were studied together with $\mathrm{Gm}$ and Inv immunoglobulin allotypes, red cell phosphoglucomutase electrophoretic types, galactose-1-phosphate uridyl transferase activity, haptoglobin types, and plasma protein electrophoresis. Haemoglobin electrophoresis was done on cellulose acetate.

\section{Case Report}

The proposita is the younger of two children, aged 20 years and 18 years, born to parents who were 35 (father)

\footnotetext{
Received 4 March 1970.

* Supported in part by Grant No. MR 0504A68 from the Division of Mental Retardation, Social and Rehabilitation Service, Department of Health, Education and Welfare; by the Institute of Child Health and Human Development Grant No. D-04612, Mental Retardation Research Center, UCLA Neuropsychiatric Institute; and by California State Department of Mental Hygiene Grant No. DMH 62-14-9.8.

+ Reprint requests should be addressed to: Robert S. Sparkes, M.D., Department of Medicine, UCLA School of Medicine, Los Angeles, California 90024, USA.
}

and 27 (mother) years of age at the time of her birth. There is no parental consanguinity and the mother has had no miscarriages. After a normal pregnancy, the proposita was delivered by elective caesarean section at full term. Her birthweight was $2580 \mathrm{~g}$. and no congenital abnormalities were noted. There is a history of neonatal colic and difficulty in sucking. She had pneumonia with a high fever at 4 months of age. Development was noted to be slow; she sat at $\mathbf{8}$ months, walked at 2 years, and did not talk until 3 years of age. Bilateral osteoclasis for extreme genu varum was performed at age 3 years. She was described as hyperactive. She did poorly in school and has attended classes for the educably mentally retarded; she has completed ten grades.

Her present psychiatric illness started in February 1968 (age 17) when she became fearful and withdrawn. Alternating periods of depression and elation followed. She was first admitted to the University of California Neuropsychiatric Institute in February 1969 for evaluation of this problem.

Physical examination was essentially normal except for a mild visual convergence insufficiency, and hypoplastic teeth (consistent with rickets). Her height and weight were $150 \mathrm{~cm}$. and $59 \mathrm{~kg}$. Psychological testing with the WAIS, Bender-Gestalt, Draw-a-Person, and Rorschach indicates she is mildly retarded. Her verbal IQ is 66 , performance IQ 57, and full scale is 60 . Urinary screentests were negative for alpha ketoacids, protein, reducing substances, and acid mucopolysaccharides; and paper chromatography for urinary amino acids was normal.

The patient's mother has a history of manic depressive psychosis; a maternal aunt and paternal uncle also had a mental illness (type unknown). There is no family history of mental retardation or congenital abnormality.

A diagnosis of manic depressive psychosis was made in the patient and the manic episodes have been well controlled with medication. The psychiatric problems in this patient are extensively described and discussed by Adams and Kivowitz (1970).

\section{Results}

The results of cytogenetic studies are summarized in Table I. In the proposita a chromosome is missing from each of the $\mathrm{G}$ and $\mathrm{C}$ groups (probably 


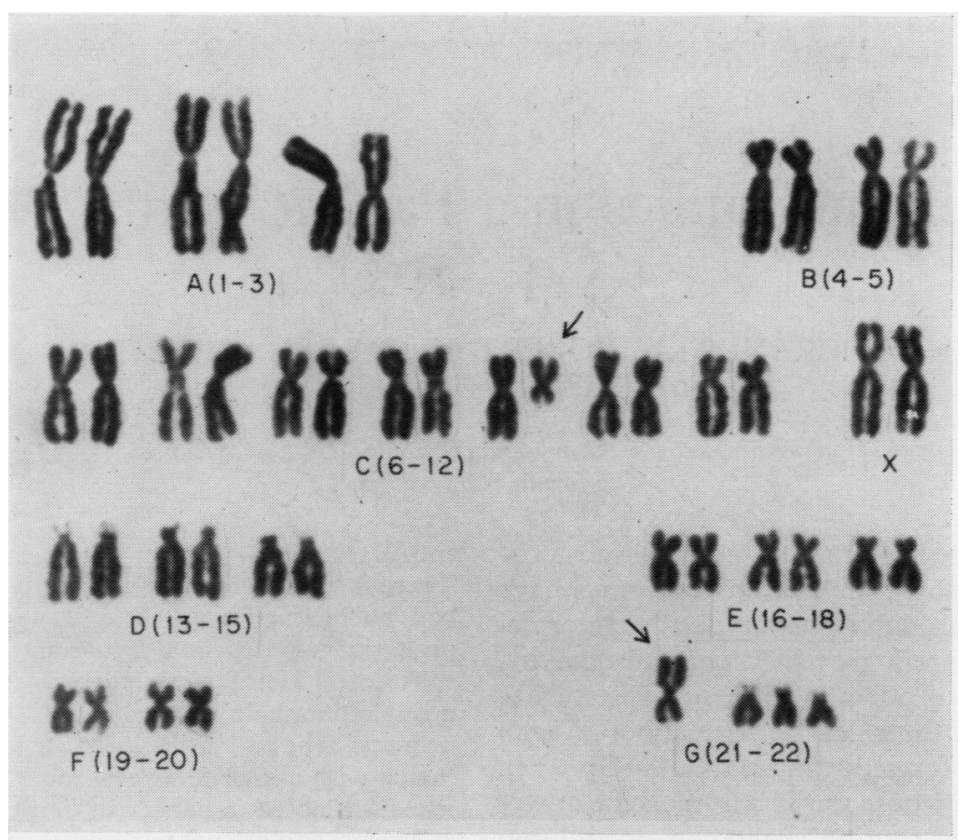

FIG. Full karyotype of the proposita showing $46, \mathrm{XX}, \mathrm{t}(\mathrm{Cq}-; \mathrm{Gp}+)$. The arrows indicate the deleted $\mathrm{C}$ group chromosome with attenuated lower ends and the $\mathrm{G}$ group chromosome with the apparent secondary constriction proximal to the translocation.

a number 10 or 11 , and there is an apparent additional No. 16 chromosome plus a small submetacentric chromosome (Fig. 1). The deleted ends of the affected $\mathrm{C}$ group chromosome appear indistinct and attenuated, suggesting satellites. This, taken with the apparent secondary constriction of the involved $\mathrm{G}$ group chromosome, suggests a reciprocal translocation between the long arms of the $\mathrm{C}$ group chromosome and the short arms of the $G$ group chromosome, giving the karyotype $46, \mathrm{XX}, \mathrm{t}(\mathrm{Cq}-$; $\mathrm{Gp}+$ ). The apparent slight increase in length of the long arms of another $\mathrm{G}$ group chromosome is probably a normal familial variant, since it is also seen in both the brother and mother. Autoradiographic studies were not helpful in further identifying the chromosomes involved in the translocation, but do show a normal appearing late labelling $\mathrm{X}$ chromosome, indicating that this chromosome is not involved in the translocation. Sex chromatin studies on the proposita demonstrate a normal female pattern. On dermatoglyphic analysis, the axial triradii are $t^{\prime \prime}$ bilaterally for the proposita and her mother, $t^{\prime}$ for her brother, and $t$ for her father. The digital patterns are not remarkable.

The results of the gene marker studies are summarized in Table II and show normal inheritance patterns. Haemoglobin $\mathrm{A}$ and $\mathrm{A}_{2}$ were present in normal proportion, as were the serum proteins. The red cell galactose-1-phosphate uridyl transferase activity was normal in both parents $(22.2$ and 27.8 ) but slightly raised in the proposita at 30.9 units (normal 18.5 to 28 ).

\section{Discussion}

During routine screening of patients with behaviour disorders, an 18-year-old girl with mental

TABLE I

RESULTS OF CHROMOSOME ANALYSES IN FAMILY MEMBERS

\begin{tabular}{|c|c|c|c|c|c|}
\hline Subject & Tissue & $\begin{array}{l}\text { Cells } \\
\text { Counted }\end{array}$ & $\begin{array}{c}\text { Modal } \\
\text { Number }\end{array}$ & $\begin{array}{c}\text { Cells } \\
\text { Karyotyped }\end{array}$ & Findings \\
\hline $\begin{array}{l}\text { Proposita } \\
\text { Brother } \\
\text { Mother } \\
\text { Father }\end{array}$ & $\begin{array}{l}\text { blood } \\
\text { skin } \\
\text { blood } \\
\text { blood } \\
\text { blood }\end{array}$ & $\begin{array}{l}38 \\
30 \\
30 \\
30 \\
30\end{array}$ & $\begin{array}{l}46 \\
46 \\
46 \\
46 \\
46\end{array}$ & $\begin{array}{r}12 \\
5 \\
5 \\
5 \\
5\end{array}$ & $\begin{array}{l}\text { 46,XX,t(Cq-;Gp +) } \\
\text { 46,XX,t(Cq-;Gp +) } \\
46, X Y \\
46, X X \\
46, X Y\end{array}$ \\
\hline
\end{tabular}


TABLE II

RED CELL ANTIGENS AND OTHER GENE MARKERS

\begin{tabular}{|c|c|c|c|c|c|c|c|c|c|c|c|c|c|c|c|}
\hline Subject & ABO & $\mathbf{R h}$ & MNSs & Lewis & Fy & $\mathbf{L u}$ & $\mathbf{K}$ & JK & $\mathbf{P}$ & Vel & Go(a) & $\mathrm{Gm}$ & $\underset{1}{\operatorname{Inv}}$ & PGM* & $\begin{array}{l}\text { Hapto- } \\
\text { globin }\end{array}$ \\
\hline $\begin{array}{l}\text { Mother } \\
\text { Father } \\
\text { Brother } \\
\text { Proposita }\end{array}$ & $\begin{array}{l}\mathbf{A}_{1} \\
\mathbf{B} \\
\mathbf{A}_{1} \mathbf{B} \\
\mathbf{A}_{1} \mathbf{B}\end{array}$ & $\begin{array}{l}\text { Rh,rh } \\
\text { Rh,rh } \\
\text { Rh,rh } \\
\text { Rh,rh }\end{array}$ & $\begin{array}{l}\mathbf{M}+\mathbf{N}-\mathbf{S}-\mathbf{s}+ \\
\mathbf{M}+\mathbf{N}+\mathbf{S}+\mathbf{s}+ \\
\mathbf{M}+\mathbf{N}-\mathbf{S}+\mathbf{s}+ \\
\mathbf{M}+\mathbf{N}+\mathbf{S}-\mathbf{s}+\end{array}$ & $\begin{array}{l}a-b+x+ \\
a+b-x+ \\
a-b+x+ \\
a-b-x-\end{array}$ & $\begin{array}{l}a+b- \\
a-b+ \\
a+b+ \\
a+b+\end{array}$ & $\begin{array}{l}a- \\
a- \\
a- \\
a-\end{array}$ & $\begin{array}{l}\mathbf{K}- \\
\mathbf{K}+\mathbf{k}+ \\
\mathbf{K}- \\
\mathbf{K}-\end{array}$ & $\begin{array}{l}a- \\
a+ \\
a- \\
a-\end{array}$ & $\begin{array}{l}\mathbf{P}_{1} \\
\mathbf{P}_{1} \\
\mathbf{P}_{2} \\
\mathbf{P}_{1}\end{array}$ & $\begin{array}{l}+ \\
+ \\
+ \\
+\end{array}$ & $\begin{array}{l}- \\
\overline{-}\end{array}$ & $\begin{array}{l}1-2-4+ \\
1-2-4+ \\
1+2-4+ \\
1-2-4+\end{array}$ & $\begin{array}{l}- \\
- \\
-\end{array}$ & $\begin{array}{l}1-1 \\
1-1 \\
1-1 \\
1-1\end{array}$ & $\begin{array}{l}2-1 \\
2-1 \\
2-2 \\
2-1\end{array}$ \\
\hline
\end{tabular}

* Red cell phosphoglucomutase electrophoretic types.

retardation and manic depressive psychosis was found to have an unusual karyotype with a chromosome missing from both the $\mathrm{C}$ and $\mathrm{G}$ groups, but containing an additional chromosome of the size of a No. 16 plus a submetacentric chromosome similar in size to one of the F group. The absence of any physical phenotypic abnormality in the patient indicates a probable balanced chromosomal constitution. The cause of her mental retardation is unknown, but other studies have shown a relation between the affective psychoses and mental retardation. For example, Duncan, Penrose, and Turnbull (1936) found $24.4 \%$ of patients with manic depressive psychosis to be mentally retarded. However, the possible aetiological relation of her mental retardation to the chromosome change cannot be excluded.

The red cell galactose-1-phosphate uridyl transferase activity was slightly raised in the proposita, and the significance of this is not known. Gene marker studies show the expected inheritance patterns and thus do not show linkage with the translocated chromosome. On dermatoglyphic analysis the proposita and her mother have axial triradii in the $t^{\prime \prime}$ position. The incidence of this finding in the normal population is $2 \%$ (Cummins and Midlo, 1961), and its significance here is not known.

The most likely explanation for the described chromosome variation in our patient is that it has resulted from a translocation. In addition to Robertsonian translocations, four other types of translocation may occur. The simple transfer of the terminal segment of one chromosome to the telomere of another requires only one break, but from work in other species appears to be very uncommon (Muller, 1932). Reciprocal translocations require two breaks while insertions and intrachromosomal shifts require three breaks each. In our patient the appearance of the affected $C$ and $G$ group chromosomes is most compatible with a reciprocal translocation involving the long arms of the group $\mathrm{C}$ chromosome and the short arms of the group $\mathrm{G}$ chromosome, giving the karyotype $46, \mathrm{XX}, \mathrm{t}(\mathrm{Cq}-; \mathrm{Gp}+)$.
The de novo occurrence of the $\mathrm{t}(\mathrm{Cq}-; \mathrm{Gp}+)$ chromosome in the phenotypically physically normal proposita contrasts with the 10 previously reported cases of similar translocations which were all inherited and were ascertained through children with congenital abnormalities (Yanagisawa, 1968; Pfeiffer, Laermann, and Heidtmann, 1967; Mikkelsen et al., 1968; Gray et al., 1966a; Gray, Dartnall, and Macnamara, 1966b; Lord, Casey, and Laurance, 1967; Weiss and Wolf, 1968). The varying phenotypes in these cases may result from involvement of different chromosomes of the $\mathrm{C}$ and $\mathrm{G}$ groups as well as duplication or deficiencies of different parts of these chromosomes.

The previous reports indicate no phenotypic effect of the translocation in the balanced carriers. However, the risk of these individuals for having unbalanced offspring has to be considered. If random segregation of homologous chromosomal material occurs at meiosis, half of the offspring should be unbalanced. However, in his study of the offspring of $D / G$ carriers, Hamerton (1968) found the incidence to be considerably less. Further, a sex difference was noted in that the risk was greater in the offspring of female carriers than in males (4:1). Because of the small number of instances studied, the actual risk of chromosomally unbalanced offspring for carriers of translocations of the $C$ and $G$ chromosomes is not known. Thus, amniocentesis should prove a valuable prenatal diagnostic aid and significantly improve the accuracy of genetic counselling for these carriers.

\section{Summary}

In the course of a routine chromosome survey of persons with psychiatric problems, a de novo balanced translocation between a group $\mathrm{C}$ and a Group $G$ chromosome was found in a physically normal 18-year-old girl with manic depressive psychosis and mild mental retardation. Family members were found to be phenotypically and chromosomally normal. This is contrasted with other reported instances of translocations involving 
C and G chromosomes which were inherited and ascertained through children with congenital abnormalities. Risks for balanced carriers of the translocation to have chromosomally unbalanced offspring and the role of amniocentesis for prenatal diagnosis are discussed.

The authors thank Dr. Phillip Sturgeon for red cell antigen and $\mathrm{Gm}$ and Inv typing, Mrs. Iris Veomett, Dr. Helga Muller, and Mrs. Maryellen Baluda for technical assistance, and Dr. E. Ziskind for kindly referring this patient.

\section{REFERENCES}

Adams, G. L., and Kivowitz, J. (1970). Manic depressive psychosis, mental retardation and chromosomal rearrangement. Archives of General Psychiatry. In the press.

Cummins, H., and Midlo, C. (1961). Finger prints, Palms and Soles. An Introduction to Dermatoglyphics, p. 319 . Dover Publications, New York.

Duncan, A. G., Penrose, L. S., and Turnbull, D. C. (1936). A survey of patients in a large mental hospital. fournal of Neurology and Psychopathology, 16, 225-238.
Gray, J. E., Dartnall, J. A., Creery, R. D. G., and Croudace, J. (1966a). Congenital anomalies due to transmission of a chromosome translocation. Fournal of Medical Genetics, 3, 59-61.

,-- , and Macnamara, B. G. P. (1966b). A family showing transmission of a translocation between a 6-12 chromosome and a 21-22 chromosome. Fournal of Medical Genetics, 3, 62-65.

Hamerton, J. L. (1968). Robertsonian translocations in man: evidence for prezygotic selection. Cytogenetics, 7, 260-276.

Lord, P. M., Casey, M. D., and Laurance, B. M. (1967). A new translocation between chromosomes in the 6-12 and 21-22 groups. fournal of Medical Genetics, 4, 169-176.

Mikkelsen, M., Mortensen, E., Shakkebaeck, N. E., and Yssing, $M$. (1968). Familial reciprocal translocation between a $C$ group (12 ?) chromosome and a late labelling G chromosome. Acta Genetica et Statistica Medica, 18, 241-250.

Muller, H. J. (1932). Further studies of the nature and causes of gene mutations. In Proceedings of the VIth International Congress of Genetics, Ithaca, p. 213. Ed. by D. F. Jones. Brooklyn Botanic Garden, New York.

Pfeiffer, R. A., Laermann, J., and Heidtmann, H. L. (1967). Reziproke Translokation zwischen einem Chromosome Nr. $21\left(\mathrm{G}_{1}\right)$ und einem Chromosom der Gruppe C (C6). Helvetica paediatrica acta, 22, 558-564.

Weiss, L., and Wolf, C. B. (1968). Familial C/G translocation causing mitotic nondisjunction. American fournal of Diseases of Children, 116, 609-614.

Yanagisawa, S. (1968). Cytogenetic studies on the mentally retarded children. Acta Paediatrica faponica, 10, 30. 